\title{
CHEMICAL ANALYSIS OF THERMO MINERAL WATERS IN PEJË BATHS
}

\author{
Gani Kastrati ${ }^{1}$, Amir Sylaj ${ }^{2}$, Bahrije Dobra ${ }^{2}$, Skender Demaku ${ }^{2 *}$ \\ ${ }^{1}$ UBT College, Department of Food Science and Technologies - Republic of Kosovo; \\ 2,2,2* University of Pristina, Department of Chemistry, Faculty of Mathematical and Natural Sciences, \\ Pristina, Kosovo; \\ "Corresponding author Skender Demaku, \\ e-mail: skender.demaku@ hotmail.com; gani.kastrati@hotmail.com;
}

Received January 2020; Accepted February 2020; Published March 2020;

DOI: https://doi.org/10.31407/ijees10.202

\begin{abstract}
In order to evaluate the possible exploitation of thermal mineral water of Peja baths, for the health needs of the population, in the rehabilitation center, which was built near these waters, so far no appropriate scientific research is taken to evaluate them. The conceptual, professional, scientific and functional solution in this regard will results in the search for a new location destined for the next projections additional pools. This should be done in order to enable the population to use this natural wealth, for health and their commercial needs. Further research is planned to be conducted for the physico-chemical characterization, which will follow up on time to time the changes in the composition of the various components of this water. The analysis of the thermos-mineral water in this work involved the determination of several physico-chemical parameters (COD, BOD, conductivity, $\mathrm{pH}$ value, etc.) and some heavy metals $(\mathrm{Cu}, \mathrm{Mn}, \mathrm{Fe}, \mathrm{Pb}, \mathrm{Cd}, \mathrm{Zn}$, etc).
\end{abstract}

Keywords: Pejë Baths; thermo mineral water; heavy metals, physical-chemical parameters. 